\title{
Media, Migration and the Borders of Fortress Europe: An Interview with David Morley
}

\author{
SARA MARINO, King's College London \\ SIMON DAWES, Université Paul Valéry, Montpellier \\ DAVID MORLEY Goldsmiths College, London
}

\begin{abstract}
In this interview, David Morley addresses the contemporary European refugee 'crisis', the representation of the 'migrant' and the increasing securitisation of Europe's borders in terms of a crisis in European political identity. Looking back on several of his own publications, as well as the work of those who have influenced him and his time as a student in the Centre for Contemporary Cultural Studies in Birmingham, Morley discusses the links between geopolitics and communications, and between the virtual and material realms, as well as the contemporary significance of mobility and re-territorialisation for understanding the causes of and responses to the current 'crisis'. Reflecting on the imperial past and uncertain future of Europe, he argues for the need to be alert for positive political opportunities within moments of disjuncture and crisis, and for an emphasis on developing new modes of everyday living.
\end{abstract}

\section{KEYWORDS}

Borders, Europe, Media, Migration, Mobility, Re-territorialisation

SIMON DAWES: You are, of course, the author of seminal texts that demonstrated how audiences interpret media texts differently depending on their life conditions and experiences $(1980 ; 1986)$. In more recent years, you've also written about mobility and the emotional disconnectedness that geographical distance and place-based 'territorial control' impose on us (2007, 221-223), and about how patterns of residence and modes of media consumption can fix identity in regressive ways and produce 'anxiety-driven rituals of exclusion' (2001). To what extent do you think that such phenomena contribute to contemporary reactions to the European refugee 'crisis'?

DAVID MORLEY: I think that the first thing to say in this context is that one must recognise how very much less mobile the world is now than it was in earlier eras of globalisation, such as that, for instance, in the period of mass transatlantic and transpacific migration between about 1880-1920. The fact of the matter is that it only a very small - and indeed, shrinking - proportion of the world's population which is mobile. The vast majority of world population, in the future, will live in the 
mega-slums of Third World cities and as such, living in poverty, with very few political rights, they will have access to neither the money nor the cultural and administrative resources with which to be mobile. For the very poor, getting across borders legally is always difficult and doing it illegally is so hideously expensive that it can leave your family in debt for a generation. Of course, in their desperation, poor people all over the world will, somehow or other, still find ways to borrow immense sums to pay the extravagant charges of people-smugglers. However, most people, in most countries, still live - and will continue to live - very local lives: the lucky ones do so by choice, having established a comfortable position of privilege for themselves, which they are reluctant to see destabilised by the arrival of unwanted others (and that category can include people whose parents were themselves migrants). At the other end of the scale, there are many people who would love to move, but they can't and they are unlikely to be able to do so.

I say that because there is sometimes an assumption that the migrant represents not only a kind of 'heroic' figure - the voluntary explorer of new worlds - but also somehow represents a portent of what the future holds for everyone. To this extent, the migrant sometimes gets figured in a way which grants them a kind of epistemologically-privileged position (for instance in the fashionable 'nomadology' of Deleuze and Guattari) comparable to that which George Lukacs allocated to the proletariat of an earlier age. In my view, most migrants - and especially the involuntary ones, whose mobility is forced on them by circumstance (whether economic, political or ecological) - have got quite enough problems, without having to also carry the burden of any displaced political fantasies.

The question of how more settled and affluent populations can best find practical ways to display forms of hospitality and assistance to displaced others fleeing desperate conditions is not one that can be solved by developing imaginary forms of solidarity based on the notion of us all being 'mobile subjects'. For historical inspiration, I would look to the dedication on the statue at Liverpool Street station in London, erected to those who helped organise with the 'Kindertransport' which brought thousands of Jewish children from Germany to safety here in Britain in the 1930s. The inscription on the monument says something like 'in memory of the achievements of ordinary people dealing with the demands of extraordinary times' - it sets the bar rather high, but it offers us a precedent of just how very much can be done in what may seem like impossible circumstances.

SARA MARINO: Recently, we have witnessed the power of social media in bringing together people from all across Britain and Europe in order to offer support to refugees. From online petitions on Twitter and Facebook groups to Refugees Welcome, an organisation that matchmakes citizens willing to share their homes with displaced people, a wave of solidarity has grown rapidly and globally. It has been said that this overwhelming response from the public has forced European governments to speak up. Do you think social media have the power to make, or to influence, political decisions?

DAVID MORLEY: I $m$ actually a bit sceptical about the idea that there is any necessarily progressive/democratic valence inscribed in the technology of what are 
now called social media. I also think the terminology is problematic, in so far as it rests on the assumption that media before Facebook, Twitter and Instagram were presumably 'non-social' - a strange assumption, as there are few media more 'social' than those of the broadcast era. Indeed, there is an argument (made by people like Leuven de Cauter) that these new social media have the downside of also functioning as what he calls crepuscular media, which allow (and perhaps even encourage) people to retreat or secede into more isolated little 'sphericules' of (already) like-minded associates. Of course, as you say, when online activity is articulated with forms of offline activism, which allow citizens to better organise themselves - so as, in the example you use, to more easily offer to share their homes with displaced people that's a very positive and imaginative intervention. However, I also think one has to be careful not to overestimate the long-term political influence of many short-term forms of 'clicktivism' - which perhaps do more for the moral conscience of the person ticking the box on the online petition than anything else.

SARA MARINO: We've seen how the image of Aylan Kurdi, the Syrian boy who drowned off Turkey, has dramatically reverberated across the globe, stirring sympathy and outrage at the perceived inaction of European countries in helping refugees. According to many, this image has provoked a very emotional call for action from the public. However, this is not the first time that photographs have led to social change, from Michael Buerk's reportage of the 1984-85 famine in Ethiopia to Kevin Carter's picture of a Sudanese child stalked by a vulture, to name just two examples. How would you contextualise the power of images in shifting public perceptions?

DAVID MORLEY: I certainly think that media coverage of these issues is very important and certain photographic images of a heart-rending sort, especially those involving children, can sometimes be particularly influential. However, I don't think that the power resides in a single image - the question is how that 'notable' image works in a particular context. It's often the longer term, less visible influence of dayto-day imagery and coverage that gradually shifts the contours of public sympathy and then there perhaps comes a moment when one image tips the balance.

The other thing here is that what you see reported in the media in most northern European countries is almost exclusively pictures of migrants' distress, of these poor, desperate people in boats or drowning in the Mediterranean. You see the failure of migrant hopes; and you are shown heart-rending footage of death and disaster at sea. But there are different forms of representation of these issues. The Swiss video maker, Ursula Biemann, approaches the question of migrants coming to Europe from their own perspective. She goes to the camps, on the far southern side of the Sahara desert where they meet to begin their journeys northwards, and shows them in the moment of optimism, as they embark full of hope, to set off across the Sahara with their Tuareg guides. You have to remember that, actually, an awful lot of them are successful. Europe represents to itself the continual failure of migrants to get into the EU, but, a lot of the time, migrants are getting into Europe - because their circumstances are so desperate that they will take unbelievable risks and are forced to be continually inventive. Biemann's point, rather like Arjun Appadurai, is to insist on recognising the positive role of the courage, imagination, invention and energy that migrants put into their odysseys! 
SIMON DAWES: You've suggested that we need a better political response to 'politically regressive forms of reactionary nostalgia' (2001, 441). Could you elaborate on what form such a response might take? How can we reconcile a critique of exclusionary strategies (such as those of EU member-states) with the accommodation of 'strategic essentialism' (of disempowered refugees, but not the dissatisfied white working-class)?

DAVID MORLEY: In terms of nostalgia and exclusionism, in Europe and beyond, it is worth referring to the exemplary work of Dubranka Ugresic and Svetlana Boym on the positive value of phenomena like 'Yugo-Nostalgia' in the Balkans and, closer to home, to the title of an article by Wendy Wheeler that I always liked, which was called 'nostalgia isn't nasty'. In that piece, she was being deliberately provocative, by saying that one might want to distinguish the politically regressive forms of nostalgia from those of a more positive kind - such as the nostalgia which can still be felt in some (now perhaps marginalised) parts of British society, for those elements of the civic culture of the pre-Thatcherite era, which attempted to integrate concerns with social welfare, social justice, fairness, equality and opportunity in some concept of a 'public good' for which everyone shared some ethical responsibility. The relative absence of that widely shared ethical sense in the dominant individualist culture of the UK today is a real loss, so far as I'm concerned: it is a matter of political urgency to re-invent it in new terms, for today`s circumstances.

SARA MARINO: Recent episodes in Calais and in the Mediterranean Sea have clearly showed that there is no such a thing as a European community when it comes to preserving human rights. On the one hand, countries such as Britain, France and Germany have reacted as isolated fortresses with no intention to collaborate for the development of universal solidarity measures. On the other hand, a laissez-faire attitude has often been privileged in order to avoid upsetting the electorate. Do you think it is still possible to imagine a genuine European identity today or maybe we should start talking about a post-Europe scenario?

DAVID MORLEY: I think there are a lot of different issues there, which probably need to be addressed separately. Let me begin with Calais. I do agree that, in the British media, the migrant camps in Calais have been incredibly rich sites for what someone like Volosinov would call the 'semiotic warfare' that has surrounded the term migrant in the recent period. I think the single most resonant moment was when one of the ultimately most conservative strands of BBC British television programming, represented by the early Sunday evening religious programme 'Songs of Praise', was broadcast from Calais in the summer. That broadcast was premised on the simple principle that, as the programme is peripatetic and as many of the migrants in the 'jungle' camp in Calais at that point were, in fact, devout Christians, it would obviously be appropriate to broadcast from their makeshift church in the camp. In fact, in a quiet way, it was political dynamite - indeed, in his end of the year 'ScreenWipe' review of 2015, the British TV critic Charlie Brooker defined that as the moment in which the media had to start recognising the humanity of the residents of 
the so-called 'jungle' camp in Calais. Furthermore, it underlined the sense in which Europe can no longer simply define itself against alterity in racial terms, (as it has for most of the postcolonial period ) but now has to also address some rather complicated matters of the (dis)articulation of some of the old patterns of ethnicity and religion. The problem in this case, for the conservative ideologies which have long dominated these debates, was that although the migrants were black, they were undoubtedly Christian - and Europe has long defined itself by reference to its Christianity - so they couldn 't be simply treated as if they represented 'matter out of place', to go back to Mary Douglas's definition of what it is that threatens ideas of cultural purity. Of course, in other contexts, and especially that of the current 'war on terror', all of that now comes back with even more of a vengeance, in so far as Europe returns to a mediaeval definition in which its Christianity is principally defined by opposition to the identity of the Muslim world. But then again, the youthful ISIS-inspired 'jihadis' currently rampaging around the cities of Northern Europe turn out to be thoroughly 'European' in many senses. They grew up in the suburbs of French and Belgian cities and hold Schengen-area passports, which, in principle, entitle them to a greater freedom of movement within Europe than that available to a white Christian citizen of a non-Schengen state, such as the UK, so 'excluding' them is going to be pretty tricky. Anyway, current state policies of securitisation risk alienating vast swathes of the Muslim population who themselves, thus far, have little sympathy with the jihadis. I mean, internment didn't work too well in Northern Ireland, as it alienated large sections of the previously conservatively-inclined Catholic population, so why would it work better against people defined as 'suspicious' simply by virtue of their being Muslim?

There's also another side to this. We can't have this discussion in terms of just the countries that are geographically 'in' Europe. You can't think about France or Britain without also taking on board the shadow of their empires and their erstwhile populations, some of whom are now resident in the imperial heartlands. The debate about "otherness" and identity in Britain started off as white British people being resentful about the presence of Afro-Caribbean and Asian people from the excolonies. But now, if you look at the right wing UKIP (UK Independence Party) it also has members who are Afro-Caribbean or Asian by ethnicity. Some of them will say "We are British, we happened, geographically, to have parents who weren't born in Britain, but who came here from the overseas Commonwealth and helped to fight in WWII and to build the Welfare State". And they say "we were born in Britain, we've been here now for a long time - but what about these Eastern European migrants?" - whom they regard as, unlike themselves, having no moral/historical claim on the UK's resources. There's a whole new fault-line there, and many white people in Britain are also now re-thinking their relation to the countries that were part of the Soviet sphere of influence - with which some feel they have less in common than they have with the culture of immigrant families from the old British Empire and Commonwealth.

There is obviously good news and bad news politically in all of those complications, but what they do tell us is that we have to keep a close eye on the internal dynamics of discourses about race, religion, migration and alterity. They are always in motion and contain internal contradictions which sometimes offer grounds for more optimism than one would first think. 
SARA MARINO: The obsession with the protection of European borders can be related to the political identity crisis that Western Europe is facing, which is partly the result of the drift to the right in European political discourse concerning issues of immigration, and partly the consequence of a massive level of unease in many Western countries, where trust in institutions and politics is at a record low (Marino 2014). What's your opinion on this matter?

DAVID MORLEY: I think you are right to speak of a massive level of unease in many Western countries, and I am sure that is, in part, responsible for the increasingly negative attitude towards Others of all kinds. However, I do think that to understand that, one has to frame the question in the context of the overall decline of the Atlanticcentred countries by comparison to the Pacific, and the relative decline of the whole rich North-West of the globe, throughout the last part of the $20^{\text {th }}$ century. Looking back now at the moment in 1989 when people like Francis Fukuyama were claiming that history was 'over' and that liberal market capitalism simply was now the only game in town, and would steadily roll onwards in conquering the world - that does increasingly look like a completely deluded picture of what was going on. Likewise, the flurry of publications which then came out in the early years of the new century with titles like 'Why Europe will Rule the World in the $21^{\text {st }}$ century' look pretty silly these days. If we think of the many historical ghosts and demons that have come back to haunt us, ever since the crisis of the Balkan wars of the 1990s, we can perhaps better see what Cornell West was going on about when he decried the notion of the 1980 s as ushering in some kind of (as it was then called) 'postmodern' era of a globalised kind. He rather sharply rephrased it as a 'regional' crisis specific to intellectuals working in the (already then) decaying public sector in countries in northern Europe (and the key postmodern writers, such as Baudrillard and Lyotard, were very Paris-focused), which had historically been accustomed to think of themselves as powerful - but which were now manifestly in decline.

Forgive me if I seem to be stepping back from the direct import of your question, but I think it's only by setting it in that much broader framework - of the overall decline of Europe on the world stage - that we can understand the desperate unease about their prospects felt now by many parts of the continent's population - and especially by the poorer, 'left behind', working class sections of European societies. To put it gnomically, I don't think that you can understand the emergence of 'Ostalgie' in postSoviet Eastern Europe societies as simply a 'local' phenomenon. As I said earlier, I think there is also a powerful form of nostalgia for the days in which, all over North West Europe, the Welfare State of the post-WWII settlement did, in fact, hold out the promise of better prospects for the future, for a majority of its citizens, and that prospect, manifestly, no longer holds good. Understandably, in that situation, those who feel that they - and perhaps even worse, their children - have been cheated, look around for someone to blame....it's a bit like an unforeseen return to the punk slogan of the 1970s, 'No Future!', only, this time around, without the spiky hair and the nihilist bravado.

In the frontispiece of Spaces of identity (1995), Kevin Robins and I quote the Cavafy poem that says "What's happened to the Barbarians? Those people were some kind of a solution - what are we going to do without them?". Ghassan Hage has a parallel, 
psychoanalytic, notion that the value of the barbarians, the migrants, the Others, is that their presence is very often used as a convenient alibi to explain why 'we' are not happy, and sadly, there is still a profound truth in that observation.

SARA MARINO: You have mentioned that European identity has been built around a negative principle; that is, the systematic exclusion of specific categories of people labelled as "other". In this respect, 'transnationalism', as a form of social activism and participation, appears the best possible way to rephrase the issue of Otherness, which might benefit in the future from a much more integrated approach, able to take into account notions of dual citizenship and dual nationality. Do you think this strategy can help to promote a more egalitarian cultural geography?

DAVID MORLEY: Well, firstly, I want to restate the proposition of my Home Territories (2000) book that, far from being a specifically European predilection, this tendency to create a sense of security by excluding Others is a (regrettably) universal, human tendency. Of course, the specific form it takes varies in different cultural contexts, and the harder and more stressful the situation, the more exacerbated it is likely to be - but the tendency is always there. For a distressing non-European example, just look at the extent of the xenophobia currently displayed in postApartheid South Africa towards black migrants from other sub-Saharan African countries. The attempt, as Julia Kristeva puts it, to accept alterity (and the unconscious, with all its embarrassing contents) in ourselves, to deal with what Kobena Mercer calls the 'sheer difficulty of living with difference' within our own communities, and to face up to the idea that democracy is always an 'agonistic' process, in Chantal Mouffe's phrase, is always hard. To that extent, I don't think that the achievement of, as you put it, a 'more egalitarian cultural geography' can be achieved simply through better political strategies or policies - important though those are. I also think it requires ongoing transformations of how we relate to alterity in our everyday lives, which I think is more affected by questions of primary socialisation, education, housing and community politics. The question, for me, is how to develop new modes of everyday living, rather than any more ethical injunctions in the abstract.

SIMON DAWES: To what extent do you think that the contemporary intensification of the legal, physical and symbolic boundaries of "Fortress Europe" is a form of "reterritorialisation'?

DAVID MORLEY: In the 90's, when Kevin Robins and I wrote Spaces of Identity, we talked about how, even in those days, we were beginning to live parts of our lives within what we called the 'electronic landscapes' created by things like satellite broadcasting systems, but we did, nonetheless, also insist on the continuing significance of what Michael Ondaatje once called 'the sadness of geography'. The problem is that 20 years later, people seem to have focused exclusively on the question of 'electronic landscapes' to the point where they imagine that we now live in an entirely disembodied and dis-embedded virtual world. That is very far from what we ever intended and I seem to spend a lot of time trying to explain that the 
question is not one of how we have now moved from an era of materiality to a totally new realm of virtual geography, but rather how the latter has become articulated with and overlaid on the former, in different ways, in particular cultural and political circumstances.

To that extent, the question in my mind has always been one of re-territorialisation, rather than de-territorialisation. The example that I have used on many occasions concerns the Call Centres which deal with customer services for many British companies. For some years now, many of these have been based outside of the geographical territory of the UK and thus they have functioned, in many people`s view, as an example of de-territorialisation - rather as if they had floated off into the ether and so could now be anywhere at all. However, the fact is that they are not beyond geography but, in fact, principally in the particular geographical territory of India which, for perfectly obvious (ex-imperial) reasons, offers British companies the attractive combination of a low-wage economy with a reasonable level of English language competence among its call-centre operatives. For similar reasons, French and Spanish call centres tend to be based in their ex-imperial territories in North Africa. Thus, the phenomena have not been de-territorialised, but simply reterritorialised - just as the derelict shipyards of Newcastle were moved to a new geographical home in low-wage Korea, and came to constitute the basis of what is now the highly successful, low-cost shipbuilding industry there.

I think, in the case of Europe, we must recognise the extent to which Fortress Europe is now being rebuilt through a combination of cultural policies (Eurimages, etc.), educational policies (Erasmus), transport policies (the Hi-Speed train projects), technical standards policies (re mobile phone networks which re-create a virtual EU as a kind of 'techno-zone'), alongside demographic and security policies designed to control the movement of bodies (increasingly restricted) without compromising the (politically desirable) movement of goods. In the book which I have just finished Communications and Mobility (Blackwell, forthcoming) I reinvoke the importance of that $19^{\text {th }}$ century geopolitical perspective on the power to control territory, even if we must now be concerned with the politics of virtual/online, as well as off-line/material territories.

However, in relation to the question of Europe's future, there are also a further set of unnerving dynamics in play, in the definition of what is - and is not - seen as properly 'belonging' to its territory. As ever, in my mind at least, all this 'futurology' necessarily links back to historical analogies - in this case, about contemporary Europe and mediaeval Christendom. Over the last 25 years the debate initiated by the Northern League in Italy has been basically about the idea (preposterous though it sounds) of drawing/building a line just south of Rome so as to just cut off the poor/backward south of Italy - which is held to be too much of a drain on the resources of the industrial North. By extension to the larger EU context, the proposal would be to draw that line so as to also eliminate Spain and Greece, and thus solve the problem of the EU's funding crisis about the needs of its poorer/profligate/irresponsible 'Southern' members. What comes to my mind here is the image of the Hanseatic League from the $15^{\text {th }}$ century, built around the richest cities of the northern European and Baltic ports. If you look at the politics of which countries took the hardest line against the Greeks, during the financial crisis of the summer of 2015, it was exactly the countries of North West Europe, where the 
Hanseatic League was founded. If this image is appropriate, then there's a rather different 'Europe' that looms not far in the future - of which Germany and Scandinavia would be the key part. It would principally be the rich North-Western part of Europe. At a cultural level, it would be very problematic if Greece was forced out - because (Classical) Greece has historically provided the very definition of what Europe is, and the source of its cultural traditions (and of the art which it badly needs global tourists to come and see, in order to balance its various economic deficits).

But as I say, all this involves a potential reconstruction of Europe, which could be rather more radical than anybody understands at the moment. It's not just a question of Greece perhaps still being pushed out of the EU system - other European countries (maybe Spain or Italy) may also be relegated to "secondary" status. Europe would then be a shrinking, and much more tightly defended, territory. There may still be a notionally inclusive Europe, at a formal level, but it may not be much like what Europe is today: it will have a very small number of rich, powerful countries at its centre, even more so than it does now, and 'Germoney' (as they sometimes now call it in Greece) will, as so often in Europe`s recent past, be the Paymaster. Underlying all that is a kind of rhetorical unconscious in the formation of the dominant concept of what 'Europe' is (i.e. Franco-Germanic + Christian) in relation to which the southern parts of the continent are seen as displaying only defective forms of their (notional or aspirational) Europeanness. However, there is an alternative starting point here which would begin with Kojeve's idea of a 'Southern European Union', originally proposed in the post-WWII period and re-articulated recently by Giorgio Agamben as the idea of a 'Latin Empire' of Southern European cultures, intended to counter the dire authoritarianism of the bankers of the North-West of the continent.

SIMON DAWES: When first developing your own theoretical-methodological approach of cultural studies and media audience ethnology, you drew in particular on sociology and cultural anthropology. More recently, you have turned to geography and transport studies, and have engaged in particular with the work of Arjun Appadurai, and the relation between virtual/symbolic and materialist geographies of exclusion (Appadurai \& Morley 2011). Could you tell us about how your interdisciplinary approach has developed over time; what specifically have you taken from each of these intellectual or disciplinary sources; and what can cultural studies and transport studies, for example, offer each other in an analysis of "Fortress Europe"?

DAVID MORLEY: The link between virtual and material realms applies particularly to the continuing significance of material geographies, even in the changed circumstances of networked societies - in which one must, of course, address questions of both topology and topography. After all, the Internet itself has a perfectly clear geography, in which Internet connectivity per square kilometre varies massively in different parts of the globe, and it turns out that, curiously enough, the Internet industry itself displays a particularly concentrated industrial structure, being mainly located in very small areas (such as 'Silicon Alley' in Shoreditch in East London, or the 'Cybersentier' district in Paris, etc.) of the global cities of our time. 
As for what I have taken from other disciplines, I suppose that the anthropologists helped me to try and avoid unproblematically EurAm-centric perspectives and to attend to the symbolic as much as the instrumental functions of technology; geographers have helped me better understand the various space-shrinking 'teletechnologies' (technologies of distance) of our age; and transport geographers helped me to rediscover the classical definition of communications - as properly concerned with the movement not only of information, but also of bodies, and commodities.

What interests me today is re-thinking the classical questions of geopolitics and communications in the "re-vivified" form that they achieve in the contemporary era. Traditionally, 'communications' functioned as a noun concerned with transport, as much as with the sending of messages, whereas nowadays we think of communication entirely as a matter of rhetoric, as only a matter of information. However, look at the way material transport links, like the high-speed railways, are reshaping Europe; they have been built on the principle of allowing businessmen from particular Northern European cities to travel the region and still get back home 'in time for dinner'. But the problem is that the more those parts of Europe are connected, the more disconnected the rest of Europe is, in so far as it is excluded from that network - so transport links are central to community-building practices, whether at local, national or continental level.

SIMON DAWES: How should contemporary migration research re-address the core questions at the forefront of the current debate? What kinds of socially/technologically deterministic or simplistic scholarly accounts of the contemporary refugee crisis have you come across, and what kinds of assumptions should be avoided? What do you think would be the most fruitful lines of inquiry for researchers interested in examining the dynamics of contemporary abstractions such as "Europe" and "migrants" in terms of media and cultural power? And do you remain convinced that such power is best understood in terms of a Gramscian model of ideology and hegemony?

DAVID MORLEY: When I was a student at the Centre for Contemporary Cultural Studies in the 1970s, the theorisation of the collapse of the British post-war consensus had just begun and its unravelling was beginning to demonstrate the first harbingers of what later became known as 'Thatcherism'. I remember the degree of scepticism with which Stuart Hall's concept of 'Thatcherism', as a specific mode of hegemony, based on a novel blend of entrepreneurial individualism and authoritarian populism, was greeted at the time. However, forty years later, we now see that variants of that particular form of hegemony - administered, in turn, by Mrs Thatcher herself, John Major, New Labour and George Osborne - still persist today. So the concept certainly seems to have proved its worth. I have yet to find a more effective way of analysing power and ideology.

I certainly don't think that either Foucault's model of 'dispersed' power or the Deleuzian models of Hardt and Negri even come close, as they are all too abstract and generalised. The same goes for the varieties of postmodern theorisation popularised by Fred Jameson, in so far as, despite its many sophistications, most of it is, in fact, based on a return to the fundamentalist Marxism of Ernst Mandel - who really did 
believe that the economic base has a given 'logic' which ultimately determines (and therefore 'explains') the cultural forms. The whole point of CCCS's long detour through Althusser and Poulantzas in the 1970s was to get away from that form of crude economic determinism. Those more abstracted models of power lack the capacity to produce effective and convincing forms of 'mezzo-analysis' - they always seek to explain the empirical level of concrete micro-events directly from the macrostructures (be they economic or technological) without reference to how those factors play out within the context of a specific conjuncture.

The great thing about the Gramscian model is that it does insist that you have to stay alive to questions of conjunctural change in how the dynamics of any particular hegemonic block are shifting at a given moment; and to where the fault-lines are that may allow effective political interventions into contemporary debates. From that perspective, things are never totally predetermined: you have to be realistic about the strength of the forces lined up against you (Gramsci`s famous 'pessimism of the intellect' which Stuart Hall was always fond of quoting). But also you need to be alert to the moments of disjuncture and crisis which present positive political opportunities : which I would argue the current crisis about migrancy itself offers, in respect of debates about Europe's future (and is thus also a political space for the exercise of the 'optimism of the will', to fill in the other half of Gramsci quote).

Let me end by saying something about the practical question of what we might best do about the particular crisis of migrancy that Europe faces at the moment. At a time when our governments are simply trying to 'outsource' the problem of border control, by turning Greece or Turkey into Europe's policemen (thus shifting Europe`s borders to the other side of the Mediterranean) perhaps the most valuable contribution we can make is to campaign against bombing or invading any more Middle Eastern countries. That misguided policy is certainly one of the short-term causes of the immediate wave of migrancy by which the EU now feels itself to be so overwhelmed. In the longer term, I think the single most important issue is campaigning for more progressive policies of debt relief in the Third World, which would give at least some of the countries which currently 'produce' very little, except large numbers of migrants, more of a chance to provide those people with a future in which they might be able to fulfil some of their dreams nearer to home - which, given the option, is probably what most of them would prefer.

\section{References}

Appadurai A. and Morley, D. G. (2011) 'Decoding, diaspora and disjuncture - Arjun Appadurai in dialogue with David Morley', New Formations, 73, 44-55

Marino, S. (2014) 'Surviving mechanisms of power in immigration strategies : embracing Otherness and pluralisms', Journal of International Political Theory, 11.2, $167-183$

Morley, D. G. (1980) The Nationwide Audience, British Film Institute 
Morley, D. G. (1986) Family Television: Cultural Power and Domestic Leisure, Comedia

Morley, D. G. (1992) Television, Audiences and Cultural Studies, Routledge

Morley, D. G. and Robins, Kevin (1996) Spaces of Identity: Global Media, Electronic Landscapes and Cultural Boundaries, Routledge

Morley, D. G. (ed.) (2000) Home Territories: Media, Mobility and Identity, Routledge

Morley, D. G. (2001) 'Belongings - space, place and identity in a mediated world', European Journal of Cultural Studies, 4.4, 425-448.

Morley, D. G. (2007) Media, Modernity and Technology: the Geography of the New, Routledge

Morley, D. G. Communications and Mobility: The Migrant, the Mobile Phone and the Container Ship Blackwell (forthcoming)

Sara Marino is a Teaching Fellow in Digital Culture at the Department of Digital Humanities at King's College London. She holds a PhD in Communication Science from the University of Urbino (Italy), where she worked on digital media and diaspora. Her doctoral dissertation, "Online and offline diasporic communities. Italians in London", examined the use and impact of Internet technology on immigrants' identity, sense of community and ideas of belonging.

She previously worked as a Visiting Lecturer at the University of Westminster, and as Associate Lecturer at Central Saint Martins - University of the Arts.

Her main research focuses on the social understanding and analysis of digital diasporas from a political economy perspective that seeks to explore how the socioeconomic European scenario has affected intra-European migration. More recently, she became interested in the study of borders and transit zones, especially in relation to the refugee crisis and to the idea of Fortress Europe.

Email: sara.marino@kcl.ac.uk

Simon Dawes is the editor of Networking Knowledge - the Journal of the MeCCSA $\underline{P G N}$, editorial projects \& website manager of Theory, Culture \& Society and Body \& $\underline{\text { Society, }}$ and editor of the media \& communication studies section of the Open Library of Humanities. He teaches at Université Paul Valéry, Montpellier, France.

His research revolves around issues of media theory, history and regulation. Last year he co-edited (with Nour Shreim) a special issue on 'Mediatizing Gaza' (2015). Currently, he is writing a monograph based on his $\mathrm{PhD}$ thesis, Broadcasting and the Public-Private Dichotomy (forthcoming, Palgrave Macmillan). 
Email: simondawes0@gmail.com

David Morley is Professor of Communications at Goldsmiths College, London University. He has held visiting positions in a number of countries and his work has been translated into 16 languages. He works on questions of cultural theory and globalisation, on processes of de/re-territorialisation, and the re-constitution of boundaries and regions. His most recent research focuses on the changing relations between the virtual and material dimensions of communications and on the articulation of the fields of media studies and cultural geography.

Email: d.morley@gold.ac.uk 